\title{
Can Forest Management in Protected Areas Produce New Risk Situations? A Mixed-Motive Perspective from the Dadia-Soufli-Lefkimi Forest National Park, Greece
}

\author{
Tasos Hovardas \\ University of Thessaly \\ Greece
}

\section{Introduction}

Sustainable forest management is conceptualized as a management system which attempts to conciliate economic, ecological, and social dimensions (Maes et al., 2011; Vierikko et al., 2008). In this direction, sustainable forest management will have to foresee mechanisms and institutional arrangements for resolving trade-offs among multiple actors with conflicting interests (Bernués et al., 2005; Van Gossum et al., 2011). Decisionmaking schemes that involve a variety of interest groups might lead to increased complexity due to the societal demand for rational and transparent deliberation processes (Brechin et al., 2002; Wolfslehner \& Seidl, 2010). A major challenge to sustainable forest management is to handle this complexity as well as confront uncertainty, which originates from changes in positions of stakeholders, scientific theories, and social institutions (Foster et al., 2010).

One response to complexity is to employ adaptive management, which presupposes feedback mechanisms and reflexive learning processes as necessary prerequisites to cope with an undetermined future and the core issues of risk and uncertainty (Plummer \& Fennell, 2009; Von Detten, 2011). However, social aspects of sustainability are frequently downplayed even in adaptive management configurations. Previous studies showed that conventional methods of social science research and widely implemented management policies might underestimate the social heterogeneity at the local level to a substantial extent (Berninger et al., 2010; Sugimura \& Howard, 2008). This inadequate handling of the social context might be expressed in matters of environmental governance. For instance, when local communities are represented by spokespersons adhering to majorities, minority positions are excluded (Hovardas et al., 2009; Hovik et al., 2010).

In the present paper we will approach the notion of sustainable forest management critically by examining the case study of the Dadia-Lefkimi-Soufli Forest National Park (DNP) in Greece. Our basic objective is to exemplify how forest management in a protected area can succeed in guaranteeing viable population sizes of endangered species but, at the same time, how it can eventuate in new risk situations regarding fire suppression and ecotourism development. Next, we will present a mixed-motive perspective formulated by local 
residents, who take advantage of the new risk situations encountered in the area and aim at the renegotiation of forest management and building a new social consensus. Finally, we will attempt a philosophical grounding of the mixed-motive perspective and we will discuss its potential contribution in promoting a new conceptualization of sustainability in forest management.

\section{The Dadia-Lefkimi-Soufli Forest National Park}

The study area is a public forest situated in north-eastern Greece next to the Greek-Turkish border (Fig. 1). The forest is dominated by Aegean pine (Pinus brutia), black pine (Pinus nigra), and oaks (Quercus frainetto, Q. Cerris, Q. pubescens). A development project funded by the World Bank in the late 1970s was about to intensify forest production, promote the clearing of oaks and reforestation with fast-growing pines. Based on a report of IUCN and WWF, the Greek Government established the Dadia Forest Reserve in 1980 by a Presidential Decree. The reserve was later included in the Natura 2000 sites proposed in Greece. The status of the reserve was further upgraded in 2006, when the protected area was recognized as a 'national park'. The park includes two strictly protected core areas (7290 ha), where all human activities are prohibited apart from those which are considered necessary for biodiversity conservation and scientific research. In the buffer zone (35170 ha), forestry is the main activity.

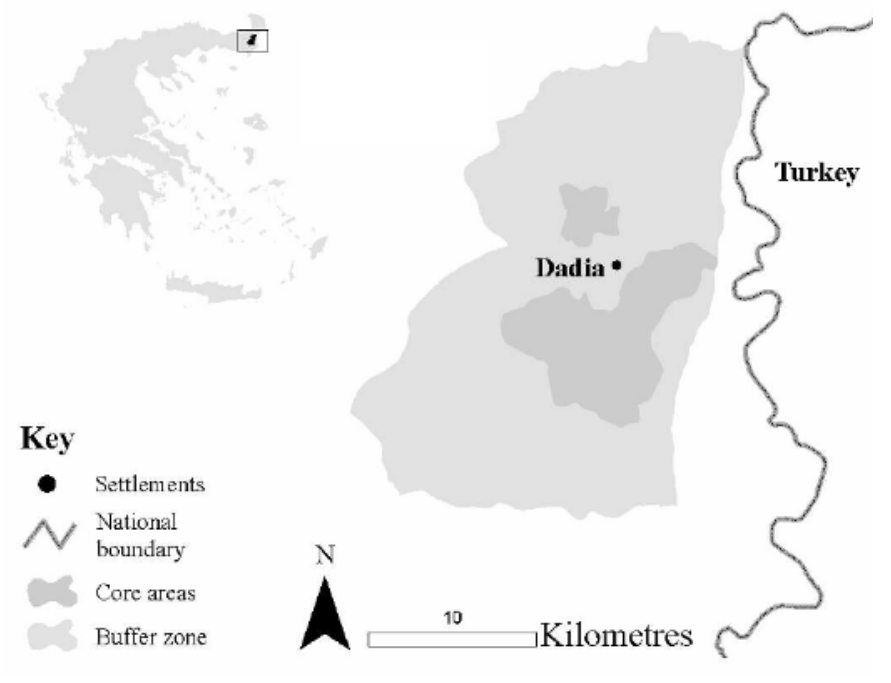

Fig. 1. The Dadia-Lefkimi-Soufli Forest National Park

Dadia is most known for its raptor fauna; thirty-six out of thirty-eight European raptor species can be observed in the park. The conservation of the black vulture (Aegypius monachus) is the central subject of forest management in the region (Adamakopoulos et al., 1995; Poirazidis et al., 2004), since DNP hosts the only breeding population of the species in 
the Balkans (Skartsi et al. 2010). The two cores have $85 \%$ cover of pinewoods and mixed pine-oak woods and are crucial as nesting sites for the black vulture (Poirazidis et al., 2004). Maps of probability of occurrence for the nest sites of black vultures showed that nests are very likely to fall within the cores of DNP (Poirazidis et al., 2004). While the population in 1979 amounted to no more than 5 breeding pairs and a total of 26 individuals, the number of birds counted today in the park may range between 70 and 80 individuals, including about 20 breeding pairs (Skartsi et al., 2010). A number of projects implemented by WWF-Greece supported the increase of the population of the black vulture (Adamakopoulos et al., 1995; Poirazidis et al., 2002), for instance, vulture food supplement is provided in a feeding table that has been landscaped in the big core of the study area. Together with vulture food supplement, prohibition of hunting as well as strict control of forestry activities and road access that may lead to breeding failure have enabled the recovery of the black vulture (Poirazidis et al., 2004; Skartsi et al., 2008).

When the protected area was established in 1980, local people opposed fiercely the suspension of logging in the core zones of the forest reserve, since the loggers' cooperative in Dadia included more than 70 members, namely, about one-tenth of the total population of the village (Catsadorakis, 2010). This negative stance gradually shifted to an acceptance of the environmental conservation regime principally due to ecotourism development (Hovardas \& Stamou, 2006a; Svoronou \& Holden, 2005). The primary sector is currently decreasing in terms of employment, while the tertiary sector, including services and tourism, is gaining importance in the local economy (Liarikos, 2010). Ecotourism has been developed around wildlife viewing. Visitors are transferred to a Bird Observatory in full view of the vulture feeding table, where they can watch vultures feeding on carcasses (Hovardas \& Poirazidis, 2006). The annual number of visitors has risen from less than 2000 in 1994 to more than 40000 today and infrastructure was gradually expanded to cover the rising demand (Hovardas, 2005). Apart from supporting ecotourism development, WWFGreece has launched since the 1980s a series of environmental awareness campaigns including the celebration of the Annual Birds' Day.

\subsection{Fire suppression in DNP}

The biodiversity in DNP has to be attributed to a highly heterogeneous patchwork of habitats which are the result of traditional activities such as livestock grazing, small-scale agriculture and logging, as well as the use of fire (Grill \& Cleary, 2003; Kati \& Sekercioglu, 2006). However, many of these anthropogenic activities have either diminished or are undertaken rather infrequently (Schindler, 2010). Analogous socio-environmental trends have been reported for other Mediterranean mountainous regions (Álvarez Martínez et al., 2011; Badia et al., 2002; Bernués et al., 2005; Tàbara et al., 2003). In accord with the regulation of logging activities after the designation of DNP, the developments that have been described above have resulted in forest expansion and a decrease of forest clearings (Triantakonstantis et al., 2006), which comprise a crucial structural component of the foraging habitat of vultures (Catsadorakis et al., 2010; Gavashelishvili \& McGrady, 2006). Therefore, protected area managers in DNP call for an urgent restoration of traditional activities with special reference made to grazing, which can halt the accumulation of dry plant biomass and reduce the risk of a wildfire (Catsadorakis et al., 2010; Poirazidis et al., 2004; Vasilakis et al., 2008). 
Despite the fact that fire has been recognized as a source of landscape heterogeneity in DNP and has contributed substantially in shaping the nesting habitat of the black vulture ${ }^{1}$ (Poirazidis et al., 2004), wildfires are acknowledged among the major threats of the park (Catsadorakis et al., 2010). Quite paradoxically, it is the 'wild', unexpected, and uncontrollable character of such a fire that is particularly alarming, causing anxiety among local residents and protected area managers in a national park. Although fire has long been considered as a natural phenomenon that determined evolutionary traits of plant species in Mediterranean ecosystems (Arianoutsou et al., 2011; Robbins, 2004), it cannot be allowed to 'return' to DNP. However, fire suppression is not a risk-neutral solution itself, since it is expected to increase surface fuel load and, thereby, foster the ignition of a wildfire (Chuvieco et al., 2010; Piñol et al., 2007; Sletto, 2010, 2011). Fortunately, DNP has not experienced any devastating event, such as the fires in Greece during the summer of 2007. The last incident of fire that has been recorded in DNP dates back to September 2008, when there were three fires ignited by lightning within one day. These fires destroyed about 60 hectares of mixed forest (i.e., pine and oak) and were put out quickly due to the immediate intervention of the Fire Service supported by local people and members of WWF Greece.

\subsection{Ecotourism development in DNP}

Ecotourism development in DNP served initially an instrumental purpose in countering negative attitudes of local people towards the environmental management regime established after the designation of the protected area and creating support for nature conservation (Liarikos, 2005; Svoronou \& Holden, 2005). Gradually, DNP has succeeded in becoming an exemplary case for ecotourism development in Greece (Hovardas \& Korfiatis, 2008; Hovardas \& Poirazidis, 2006). Recent trends show that annual visitor numbers tend to stabilize around 40000 visitors following a slight decrease after 2003 (Liarikos, 2010). Despite these numbers, the majority of visitors display soft ecotourism-type characteristics, namely, short duration of stay, relatively large visitor group size, and trip organization by travel agents (Hovardas \& Poirazidis, 2006), which results in little income generated for local residents (Catsadorakis et al., 2010). Protected area managers urged for the revision of the ecotourism development strategy and an improvement of the ecotourism product so that high-value visitors are attracted and uncertainty among local entrepreneurs is relaxed (Catsadorakis et al., 2010).

High levels of overall visitor satisfaction have been recorded in Dadia (Arabatzis \& Grigoroudis, 2010; Hovardas \& Poirazidis, 2006). However, a satisfactory general impression from the visit can coexist with identification of problems signaling a possibility of being close to reach natural or social carrying capacities (Machairas \& Hovardas, 2005). In an evaluation of ecotourism in Dadia (Hovardas \& Poirazidis, 2006), watching birds at the Bird Observatory revealed relatively low levels of visitor satisfaction, which was attributed to visitors' frustration when they are not fortunate in watching vultures. There is a pressing need to diversify activities offered to visitors in DNP and reduce the dependence of the visit on the Bird Observatory Post, which will also assist considerably in avoiding any possible disturbance of vultures (Liarikos, 2005). Indeed, the primary concern voiced over

\footnotetext{
1 The optimal nesting habitat of the black vulture in Dadia includes mature trees located in steep slopes, which are surrounded by openings or with low height vegetation. Fire was a crucial component in the formation of black vulture's nesting habitat (Poirazidis et al., 2004).
} 
ecotourism development is the apparent vulnerability of fragile natural environments to degrading impacts stemming from excessive visitor numbers (Ólafsdóttir \& Runnströ, 2009). Despite the potential it can offer for marginal areas (Hovik et al., 2010), tourism development has been characterized as a fickle endeavour, where precise forecasts are not possible (Cole \& Razak, 2008). Ecotourism scholars have highlighted the tendency of tourism for accelerating growth (Butler, 1999; Fennell \& Ebert, 2004; Eagles, 2002; Lawson et al., 2003). This opportunistic character of tourism is reinforced in protected areas under the withdrawal of primary sector activities (Puhakka et al., 2009; Sharpley \& Pearce, 2007).

\section{The emergence of new risk situations in DNP}

\subsection{The 'eviction' of fire from DNP and its come-back as a new risk situation}

Much modern environmental thinking stems from the balance-of-nature metaphor (Hovardas \& Korfiatis, 2011). According to this metaphor, natural systems tend towards a point of relative stability. Systems in equilibrium resist change and when balance of nature is upset by human intervention, self-regulatory forces work to return the system to the state of equilibrium. Nature conservation in the form of establishing and operating protected areas has been based on the balance-of-nature metaphor and on the separation of the natural realm from the social realm by the demarcation of boundaries (Diamond, 1975). Although the balance-of-nature metaphor has been challenged by developments in the field of ecology (Hovardas \& Korfiatis, 2011), it still continues to determine perceptions and policies related to nature conservation (Clapp, 2004; Nygren, 2000; Durand \& Vázquez, 2011).

With the balance-of-nature metaphor acting as an organizing principle, the ecological discourse refers to a political project which wishes to establish a 'state of lost harmony' (Stavrakakis, 1999). The illusory character of the harmonious image of nature is revealed by manifestations of elements which cannot be accommodated by the balance-of-nature metaphor and assume a symptomatic form ${ }^{2}$ (Stavrakakis, 1999). In order for nature-inbalance to remain coherent, any evidence that is not compatible with this image and threatens to destabilize it has to be repressed and excluded from nature's symbolization. However, under this Lacanian frame, we have to accept that no repression can guarantee the disappearance of the undomesticated, excluded symptom, which should be expected to return to its place at an unsuspected time (Stavrakakis, 1999). It is in this way that fire is rendered a symptom exactly when it should be expected with certainty. A wildfire, which is a quite common phenomenon in forests all along the Mediterranean Basin, would have irreversible consequences for biodiversity conservation, ecotourism, and the local community in Dadia. Agee (1997) underlines that few managers plan for a devastating fire and they just hope that it will not occur on their watch. Yet, the event of an unexpected and unmanageable wildfire can never be excluded (Klenner et al., 2000).

\subsection{The irreducible interrelatedness of society and nature}

Instead of conceptualizing DNP as some kind of intact nature demarcated within park borders, we should perceive it as a new spatial configuration produced by a special forest management regime (Robbins, 2004). For instance, the reconfiguration of space through zoning in Dadia has been centered around the priority of black vulture conservation

2 The 'symptom' is an element which is thought to introduce disharmony in a symbolization that would otherwise be coherent and harmonious (Stavrakakis, 1999). 
(Poirazidis et al., 2004). In contrast to core zones which include black vulture nests, the buffer zone presents an overall higher diversity of habitats and taxa (Grill \& Cleary, 2003; Kati \& Sekercioglu, 2006; Kati et al., 2004; Schindler et al., 2008). DNP provides a case study for the challenges presented to protected area managers, which are result of delineation of boundaries (Fall, 2002). Managers have to maintain these boundaries that protect biodiversity and, at the same time, they have to strive to diminish the negative effects that are recognized as consequences of these same boundaries (Knight \& Landres, 1998). Managers need to tightly control nature within park borders in order to maintain desired conditions (Wood, 2000). However, strict territorial control frequently leads to the production of a static, ahistorical space (Roth, 2008). This is exemplified in Dadia by the 'eviction' of fire from DNP. Although fire is a feature which has shaped Mediterranean ecosystems, both society and nature in Dadia cannot be reproduced unless fire is suppressed.

A static, ahistorical nature has to be matched against a society that shares analogous properties. This is exemplified in the measures proposed by protected area managers where activities such as grazing and agriculture are referred to as 'traditional'. One way of reading this adjective is that it addresses small-scale activities, which should be taken in contradistinction to large-scale mechanized agriculture or stock breeding. However, another way of conceptualizing the need of restoring 'traditional' activities is their supposed compatibility with protected area governance, since 'traditional' might denote a state of local community that can be integrated in the park. In this direction, analysis of the local press (Hovardas \& Korfiatis, 2008) and of the textual material disseminated in the Information Center of Dadia (Stamou et al., 2009) has shown that production processes are hushed up, which obscures the competition between different land uses and social actors in the area. Quite interestingly, this eventuates in sealing off the production process that has resulted in the ecotourism product offered to visitors (Hovardas \& Korfiatis, 2008). Such discursive practices that both produce and limit meaning foster the belief of an independent nature which is to be encountered in the Bird Observatory Post or while walking along trails in the forest (Stamou et al., 2009).

Rather than adopting a dualistic approach to address the relationship between society and nature, which opposes society to nature, or a monistic approach, which collapses the natural realm into the social or vice versa, we subscribe to a dialectical position. Our assumption is that society and nature are simultaneously shaping and being shaped by each other, while each maintains a measure of autonomy (Evanoff, 2005). In this dialectical perspective human societies are seen in relational terms as both constituting and being constituted by the environments they inhabit, which has important ontological and epistemological implications. 'Forests' do really exist and are to be found 'out there' independently of our existence and of our definitions (ontological assumption). However, there is no cognitive appropriation of any 'forest', which could provide an objective, socially and culturally unmediated access to some type of essence of this notion (Robbins, 2004). Namely, the cognitive appropriation of 'forests' is always socially and culturally embedded (epistemological assumption).

\subsection{How many visitors are enough?}

The calculation of the carrying capacity of DNP for ecotourism development has been considered as a crucial prerequisite for respecting core prescriptions of sustainability 
(Svoronou, 2000). Most definitions of carrying capacity of destinations for tourism development involve two components: one relating to environmental impacts (natural carrying capacity) and a second one relating to the quality of the recreational experience (social carrying capacity) (Lawson et al., 2003; Seidl \& Tisdell, 1999). The notion of carrying capacity implies a threshold of visitor numbers that corresponds to the maximum level of use that a destination can accommodate without unacceptable alteration in environmental aspects or in the quality of visitor experience (Sæpórsdóttir, 2010).

Despite the fact that carrying capacity indicators are considered as a crucial tool for determining levels of use and monitoring tourism development, there are many reservations expressed about the possibility of singling out consistent thresholds and clear benchmarks for quantifying carrying capacity (Fleishman \& Feitelson, 2009; Manning et al., 2002). A number of studies attempted to incorporate stochastic and fuzzy decision rules in the estimation of carrying capacity to account for variability and uncertainty in observed indicators (Prato, 2001, 2009). Further, there can be substantial divergence between the natural carrying capacity and the social carrying capacity estimated for the same destination (Zacarias et al., 2011). Moreover, positive indicators (e.g., user satisfaction) might remain over minimum acceptable levels, while negative indicators (e.g., soil erosion from trails) are surpassing maximum acceptable rates. Additional difficulties in determining carrying capacity include uncorrelated crowding perceptions with actual visitor numbers and differences among various visitor groups in tolerating crowding (Leujak \& Ormond, 2007). A final remark concerning the contribution carrying capacity in adaptive management relates to its reactive nature (Fleishman \& Feitelson, 2009; Lawson et al., 2003): remediary action is initiated only after standards of quality have been violated or are close to be violated.

A question that arises at this point is how carrying capacity can still be regarded as an important management tool in the light of all these reservations concerning its estimation. Handling risk perception in the case of carrying capacities needed desperately for guaranteeing sustainable tourism development in Dadia would necessitate to rename uncertainty into a number of visitors or a range of acceptable natural and social conditions. However, the field of risk perception addresses any objective account of carrying capacities as naïve and maintains that thresholds and benchmarks are not simply derived by scientific measurements of natural attributes but result from motivations and interests of various competing stakeholders which are being projected to nature (Bradley \& Morss, 2002). This critical reading recognizes the need of adaptive management but rejects any sharp distinction of 'brute' facts from values (Giessen et al., 2009; Ruppert-Winkel \& Winkel, 2011; Warren, 2007). However, there is a possibility that the adoption of this critical perspective might end up in an absolute and unproductive relativism, which would ultimately question the background assumptions of adaptive management. Below we will see how the mixedmotive perspective of local residents in Dadia avoids such a relativistic outcome and how locals attempt to negotiate ecotourism development in the region.

\section{From a 'Greens know best' perspective to a 'Nobody knows best' perspective}

The history of forest management in Dadia can be reconstructed as a contradistinction of incompatible perspectives (Lebel et al., 2004), which comprise coherent sets of goals, beliefs and methods, guide decisions, and prioritize societal choices. The establishment of the 
Dadia Forest Reserve in 1980 has been launched as an initiative of IUCN and WWFInternational under a 'Greens know best' perspective, where scientific knowledge produced by environmental nongovernmental organizations was utilized as the knowledge base, which legitimized and guided forest management with a primary focus on biodiversity conservation. The fierce opposition of local people after the designation of the reserve can be understood within the frame of a 'Locals know best' perspective, where local knowledge based on local experiences and embedded in social practices was contrasted to scientific knowledge in order to delegitimize the privileged access of environmental nongovernmental organizations to decision making for forest management issues. Quite paradoxically, long-lasting weaknesses of the government apparatus in the Greek case and the recent financial crisis seem to have enrolled forest management in Dadia in institutional forms and arrangements that adhere to a negative version of a 'State knows best' perspective, where outdated legislation and shrinkage of public funding are recognized as core impediments to sustainable forest management. The establishment of Management Authorities for 27 protected areas in Greece in 2002, including Dadia, should be recognized as a move towards a 'Nobody knows best' perspective, where all interest groups are called to share the responsibility for the organization of social consensus in forest management. According to this perspective, a critical approach is necessary for building on both scientific knowledge systems and local knowledge systems. Further, uncertainties in forest management and trade-offs between different interests are acknowledged as ubiquitous and are handled by means of participatory institutional arrangements that need to become adaptive.

Under the 'Nobody knows best' perspective, contingency and 'not knowing' should be conceived as a precondition of freedom and choice of action, which provides a requested sense of controllability over the decision-making process (Keskitalo \& Lundmark, 2010) and precludes powerful partners from determining the outcome unilaterally (Von Detten, 2011). Social partners are engaged in a procedure of mutual learning (Wynne, 2006), where experts are expected to question conventional wisdom, while lay people are expected to question expert assumptions (Parkins, 2006; Risse, 2000). However, 'sharing responsibilities' might be in itself far from adequate for facing the new risk situations which have been described previously. A new, affirmative conceptualization of sustainability in forest management is needed to guide decision-making under the urgency of risk and uncertainty and to guarantee public involvement and the contribution of all interest groups towards a common vision.

\section{An attempt for an affirmative approach to sustainable forest management when 'nobody knows best'}

\subsection{Local participation in protected area governance and issues of accountability and trust}

Protected area establishment and operation has frequently resulted in a clash between local communities and scientific experts (Hovik et al., 2010; Keskitalo \& Lundmark, 2010; Laudati, 2010; Reser \& Bentrupperbäumer, 2005). In this conflict, experts appear as the group that can guarantee scientific rationality, while local people point to their right to use natural resources (Clapp, 2004). Inclusionary models of environmental governance in contemporary planning share the premise that local inhabitants participation is a prerequisite of an effective management strategy (Aasetre, 2006; Ellis \& Porter-Bolland, 2008; Kingsland, 2002; 
Kleinschmit et al., 2009; Velázquez et al., 2009). At the same time, the inclusion of societal actors poses the question of accountability and legitimacy (Kleinschmit et al., 2009). Indeed, the lack of accountability and transparency between experts and the public has been highlighted as a considerable disadvantage of protected area governance (Apostolopoulou \& Pantis, 2010; Dearden et al., 2005; Lund et al., 2009), which becomes increasingly important in situations of risk and uncertainty (Von Detten, 2011).

More often than not, initiatives to engage local stakeholders as partners in protected area governance have served as a means of countering local opposition to nature conservation and have not been organized as strategic institutional structures to mediate and reconcile opposing views on conservation (Hovik et al., 2010; Uddhammar, 2006). Environmental education interventions have commonly targeted local communities in protected areas with the central aim to transmit scientific knowledge under the anticipation that local attitudes and behaviors will be transformed by scientific accounts to align with nature conservation values and expectations (Durand \& Vázquez, 2011; Nygren, 2004). Next to the contested approach to environmental education that these interventions follow (Hovardas, 2005), they reveal that equality in terms of participation and inclusion is not always accompanied by a corresponding equality in determining the outcome of participatory processes. This instrumental view of public involvement might acknowledge local communities as key actors in protected area management but local people are eventually treated as beneficiaries of projects that have been designed without their input and consent (Durand \& Vázquez, 2011). The end result is that certain privileged groups still dominate decision-making practices despite the fact that the rhetoric of participatory governance has become a commonplace (Ojha et al., 2009).

Recent research has shown that the environmental discourse has diffused in rural areas (Hovardas et al., 2009). This is also valid in the case of Dadia (Hovardas \& Stamou, 2006b). Although local communities in protected areas might have adopted core requirements of environmental conservation, this trend should not be perceived as an unproblematic adherence of local people to join the coalition of conservationists. What is needed for the promotion of effective local participation schemata and the organization of social consensus regarding natural resource management is power sharing between local people and experts (Arts \& Buizer, 2009; Hovik et al., 2010). Unless this precondition is met, scientific experts will become so powerful in any type of deliberation process that local people or their interests will be excluded (Giessen et al., 2009; Lövbrand, 2009; Steffek, 2009) and the democratic legitimacy of the process will be severely undermined (Csurgó et al., 2008; Kleinschmit et al., 2009). An important barrier that has to be overcome in this respect is the restoration of trust between social actors with competing interests and powers. How can experts trust local people in issues that need to be based on the scientific background of forest management? On the other hand, how can rural residents in protected areas renounce their legitimate claims on the land and resources in their region?

\subsection{The mixed-motive perspective of local people in DNP}

The mainstream sustainable development discourse has been based on the predominant belief in 'win-win' options, namely on the potential reconciliation of economic and environmentalist interests (Arts \& Buizer, 2009; Durand \& Vázquez, 2011; Huttunen, 2009; Mulvihill \& Milan, 2007; Veenman et al., 2009). However, 'win-win' conceptualizations fall short of addressing the issues of accountability and trust which have been described 
previously and point towards a 'win-lose' arrangement. Further, 'win-win' options cannot explain the dynamics of competition and negotiation between social actors before and after an agreement has been reached. The question is if there is any other possibility to conceptualize the interplay or contradistinction between nature conservation and economic development apart from naïve 'win-win' or tense 'win-lose' approaches. An alternative conceptualization might be indicated by the notion of distributive justice, which implies the allocation of benefits and burdens of an activity among affected social actors (Pelletier, 2010).

Local residents' dispositions (Table 1; for a detailed description of the methodology see Hovardas, 2010) can be interpreted as a mixed-motive perspective, which diverges from 'win-win' and 'win-lose' approaches in that it envisages gain solutions for both nature conservation and economic development while acknowledging that there will always be a distributive aspect (Hoffman et al., 1999; Hovardas \& Korfiatis, 2008).

\begin{tabular}{lll}
\hline & \multicolumn{1}{c}{ Economic development } & Nature conservation \\
\hline Mutual gain & $\begin{array}{l}\text { Creating forest clearings would } \\
\text { provide significant additional } \\
\text { income for local loggers }\end{array}$ & $\begin{array}{l}\text { Forest clearings in core } \\
\text { areas would severely } \\
\text { decrease the probability of } \\
\text { a forest fire } \\
\text { Forest clearings would } \\
\text { enable raptors to find } \\
\text { their prey much easier }\end{array}$ \\
& $\begin{array}{l}\text { Trees to be cut should be } \\
\text { selected on biodiversity } \\
\text { conservation criteria } \\
\text { Extensive reforestation } \\
\text { programs should be banned }\end{array}$ & $\begin{array}{l}\text { Investment in ecotourism } \\
\text { should be enhanced as a } \\
\text { supplementary source of } \\
\text { revenue for locals }\end{array}$ \\
& & \\
\hline
\end{tabular}

Table 1. Local residents' mixed-motive approach

As solutions to forest management disputes require the balancing of interests among a complex array of participants, and because this can only be achieved through negotiations inevitably associated with costs and benefits (frame of reference in win-lose models), the mixed-motive model offers a theoretical and empirical alternative to the opposing 'win-win' and 'win-lose' perspectives. In this regard, the range of players' interests does not bifurcate into simply economic development and nature conservation coalitions but there can be a mutual recognition and appraisal of interests, which is necessary for reaching an agreement. This confrontation of social actors might increase complexity considerably but it tends to involve greater opportunities to expand the scope of the debate, finding solutions that will improve the potential outcome simultaneously for both parties (integrative principle of winwin models).

Local people in Dadia claim that creating forest clearings would provide significant additional income for local loggers. At the same time, local people suggest that forest clearings in core areas would severely decrease the probability of a forest fire and enable raptors to find their prey much easier. In terms of distributive aspects, local residents accept that trees to be cut should be selected on biodiversity conservation criteria and that extensive reforestation programs should be banned. However, they expect investment in ecotourism to be enhanced so that ecotourism development will continue to comprise a 
supplementary source of revenue for the local community. Interestingly, the new risk situations arising in Dadia are grasped by locals in their argumentation (e.g., forest fire susceptibility as well as ecotourism development). This is a strong indication that the mixedmotive perspective might allow for the incorporation and negotiation of risk situations and potential responses among interest groups involved in forest management. It should also be noticed that nature conservation gains and distributive aspects of economic development were more prominent in local accounts than other elements in the presentation of their mixed-motive perspective. This might imply the attempt of local people to engage viewpoints which would be endorsed by park managers.

In terms of distributive aspects concerning economic development, local residents seem to acknowledge the need of multipurpose forest management and their suggestions follow closely the recommendations of park managers in Dadia (Catsadorakis et al., 2010; Gatzogiannis \& Poirazidis, 2010). The economic gains they anticipate together with the gains expected for nature conservation can be inscribed in a 'productive forest' perception of forest health (Warren, 2007), which underlines the double objective of providing jobs in the forest industry while reducing the risk of wildfire. In that respect, local residents in Dadia present a position close to the emerging preventative paradigm in Mediterranean forested landscapes (Tàbara et al., 2003), which highlights the need to anticipate the intrinsic tendency of fire ignition as the highest priority. Finally, local people present ecotourism development as a distributive aspect related to nature conservation, since further investment in ecotourism would necessitate the reallocation of resources at the disposal of protected area managers for monitoring purposes and might initiate heated debates over natural and social carrying capacities. This position might indicate an implicit attempt to relate the risk concerning local unemployment rates attributed to the forest management regime to the risk of ecotourism development overriding carrying capacity thresholds. It has been reported that the existence of alternative branches of employment mediates views on the vulnerability of local forestry to nature conservation (Keskitalo \& Lundmark, 2010; Stoffle \& Minnis, 2008).

\section{Conclusion}

The Habermasian window of opportunity offered by the mixed-motive perspective is both timely and spatially delineated and guarantees the inclusion of all affected actors under a commitment of rational argumentative deliberation (Carvalho-Ribeiro et al., 2010; Durand \& Vázquez, 2011; Kleinschmit et al., 2009; Ojha et al., 2009; Parkins \& Davidson, 2008; Warren, 2007). However, conflict and negotiation should be acknowledged as indispensable constituents of a mixed-motive deliberation process. Foucauldian power differentials are not hidden between participating actors but have to be enacted to steer the negotiation or renegotiation process. This enables hidden power structures to surface and be contested and provides instances for shifting power balances and multiple empowering effects (Berman Arévalo \& Ros-Tonen, 2009; Winkel, in press). Social actors that participate will have to recognize both conflicting demands as well as the need to come to terms after negotiation. In this direction, claims of objective truth and of a single rationality have to be singled out as inadequate to serve the democratic mandate (Winkel, in press). Starting from the fact that uncertainty is irreducible by science (Borchers, 2005), social consensus is necessary to guide forest management decisions (Parkins, 2006). The possibility of any hegemonic attempt or discursive practice to frame the issue at stake will be counterweighted by declaring 
willingness to reach an agreement (Van Gossum et al., 2011) and being committed to support the final decision, against which negotiating social actors will be held accountable (Brechin et al., 2002).

'Final' in this case does not imply the possibility of any permanent solution but wishes to denote the outcome of a process, which will guide forest management for a certain period of time within a culture of experimentation. The final decision will always be marked by its temporary character, being subject to scrutiny and critical reappraisal. Within this frame, deliberation has to be considered as an incomplete process under the need of regular revision (Buizer \& Van Herzele, in press), which is perfectly compatible with adaptive management. The mixed-motive perspective can be used for scenario analysis and planning, which is a tool for assessing alternative strategies under conditions of uncertainty and for guiding adaptive management (Swart et al., 2004; Von Detten, 2011). Different scenarios can be developed as narrative descriptions of alternative hypothetical futures especially when managers cannot anticipate future conditions by extrapolating from past trends (Daconto \& Sherpa, 2010). In these scenarios, all affected social actors will have the opportunity to claim their participation.

\section{Acknowledgments}

I am grateful to Kostas Poirazidis for his multifarious help. I also wish to thank local residents in Dadia for their valuable input.

\section{References}

Aasetre, J. (2006). Perceptions of communication in Norwegian forest management. Forest Policy and Economics, Vol.8, No.1 (January 2006), pp. 81-92, ISSN 13899341

Adamakopoulos, T.; Gatzogiannis, S. \& Poirazides, K. (1995). Environmental Study of the Dadia Forest Reserve. ACNAT Programme, WWF-Greece, EU DG XI, Ministry of Environment, Physical Planning and Public Works, Athens

Agee, J. K. (1997). The severe weather wildfire - Too hot to handle? Northwest Science, Vol.71, No.2 (May 1997), pp. 153-156, ISSN 0029344X

Álvarez Martínez, J.-M.; Suárez-Seoane, S. \& De Luis Calabuiga, E. (2011). Modelling the risk of land cover change from environmental and socio-economic drivers in heterogeneous and changing landscapes: The role of uncertainty. Landscape and Urban Planning, Vol.101, No.2 (May 2011), pp. 108-119, ISSN 0169-2046

Apostolopoulou, E. \& Pantis, J. D. (2010). Development plans versus conservation: explanation of emergent conflicts and state political handling. Environment and Planning A, Vol.42, No.4, pp. 982-1000, ISSN 0308518X

Arabatzis, G. \& Grigoroudis, E. (2010). Visitors' satisfaction, perceptions and gap analysis: The case of Dadia-Lefkimi-Souflion National Park. Forest Policy and Economics, Vol. 12, No.3 (March 2010), pp. 163-172, ISSN 1389-9341

Arianoutsou, M.; Koukoulas, S. \& Kazanis, D. (2011). Evaluating post-fire forest resilience using GIS and multi-criteria analysis: An example from Cape Sounion National Park, Greece. Environmental Management, Vol.27, No.3 (March 2011), pp. 384-397, ISSN 0364152X 
Arts, B. \& Buizer, M. (2009). Forests, discourses, institutions - A discursive-institutional analysis of global forest governance. Forest Policy and Economics, Vol.11, No.5-6 (October 2009), pp. 340-347, ISSN 1389-9341

Badia, A.; Saurí, D.; Cerdan, R. \& Llurdés, J.-C. (2002). Causality and management of forest fires in Mediterranean environments: an example from Catalonia. Environmental Hazards, Vol.4, No.1 (March 2002), pp. 23-32, ISSN 1464-2867

Berman Arévalo, E. \& Ros-Tonen, M. A. F. (2009). Discourses, Power Negotiations and Indigenous Political Organization in Forest Partnerships: The Case of Selva de Matavén, Colombia. Human Ecology, Vol.37, No.6 (December 2009), pp. 733-747, ISSN 03007839

Berninger, K., Adamowicz, W., Kneeshaw, D., \& Messier, C. (2010). Sustainable forest management preferences of interest groups in three regions with different levels of industrial forestry: An exploratory attribute-based choice experiment. Environmental Management, Vol.46, No.1 (July 2010), pp. 117-133, ISSN 0364152X

Bernués, A.; Riedel J. L.; Asensio, M. A.; Blanco, M.; Sanz, A.; Revilla, R. \& Casasús, I. (2005). An integrated approach to studying the role of grazing livestock systems in the conservation of rangelands in a protected natural park (Sierra de Guara, Spain). Livestock Production Science, Vol.96, No.1 (September 2005), pp. 75-85, ISSN 03016226

Borchers, J. G. (2005). Accepting uncertainty, assessing risk: Decision quality in managing wildfire, forest resource values, and new technology. Forest Ecology and Management Vol.211, No.1-2 (June 2005), pp. 36-46, ISSN 0378-1127

Bradley, B. S. \& Morss, J. R. (2002). Social construction in a world at risk: Toward a psychology of experience. Theory and Psychology, Vol.12, No.4 (August 2002), pp. 509-531, ISSN 0959-3543

Brechin, S. R.; Wilshusen, P. R.; Fortwangler, C. L. \& West, P. C. (2002). Beyond the square wheel: Toward a more comprehensive understanding of biodiversity conservation as social and political process. Society and Natural Resources, Vol.15, No.1, pp. 41-64, ISSN 0894-1920

Buizer, M. \& Van Herzele, A. (in press). Combining deliberative governance theory and discourse analysis to understand the deliberative incompleteness of centrally formulated plans. Forest Policy and Economics, doi:10.1016/j.forpol.2010.02.012, ISSN 1389-9341

Butler, R. W. (1999). Sustainable tourism: A stateof-the-art review. Tourism Geographies, Vol.1, No.1 (February 1999), pp, 7 - 25, ISSN 1461-6688

Carvalho-Ribeiro, S. M.; Lovett, A. \& O'Riordan, T. (2010). Multifunctional forest management in Northern Portugal: Moving from scenarios to governance for sustainable development. Land Use Policy, Vol.27, No.4 (October 2010), pp. 11111122, ISSN 0264-8377

Catsadorakis, G. (2010). The history of conservation efforts for the Dadia-Lefkimi-Soufli Forest National Park. In: The Dadia-Lefkimi-Soufli Forest National Park, Greece: Biodiversity, Management and Conservation, Catsadorakis, G., \& Källander, H. (Eds.), pp. 241-252. WWF-Greece, ISBN 978-960-7506-10-8, Athens

Catsadorakis, G., Kati, V., Liarikos, C., Poirazidis, K., Skartsi, Th., Vasilakis, D., \& Karavellas, D. (2010). Conservation and management issues for the Dadia-LefkimiSoufli Forest National Park. In: The Dadia-Lefkimi-Soufli Forest National Park, Greece: 
Biodiversity, Management and Conservation, Catsadorakis, G., \& Källander, H. (Eds.), pp. 265-279. WWF-Greece, ISBN 978-960-7506-10-8, Athens

Chuvieco, E.; Aguado, I.; Yebra, M.; Nieto, H.; Salas, J.; Martín, M. P.; Lara Vilar, L.; Martínez, J.; Martín, S.; Ibarra, P.; de la Riva, J.; Baeza, J.; Rodríguez, F.; Molina, J. R.; Herrera, M. A. \& Zamora, R. (2010). Development of a framework for fire risk assessment using remote sensing and geographic information system technologies. Ecological Modelling, Vol.221, No.1 (January 2010), pp. 46-58, ISSN 03043800

Clapp, R. A. (2004). Wilderness ethics and political ecology: remapping the Great Bear Rainforest. Political Geography, Vol.23, No.7 (September 2004), pp. 839-862, ISSN 09626298

Cole, S. \& Razak, V. (2008). How far, and how fast? Population, culture, and carrying capacity in Aruba. Futures, Vol.41, No.6 (August 2009), pp. 414-425, ISSN 0016-3287

Csurgó, B.; Kovách, I. \& Kučerová, E. (2008). Knowledge, power and sustainability in contemporary rural Europe. Sociologia Ruralis, Vol.48, No.3 (June 2008), pp. 292312, ISSN 00380199

Daconto, G. \& Sherpa, L. N. (2010). Applying scenario planning to park and tourism management in Sagarmatha National Park, Khumbu, Nepal. Mountain Research and Development, Vol.30, No.2 (May 2010), pp. 103-112, ISSN 02764741

Dearden, P.; Bennett, M. \& Johnston, J. (2005). Trends in global protected area governance, 1992-2002. Environmental Management, Vol.36, No.1 (July 2005), pp. 89-100, ISSN $0364152 X$

Diamond, J. (1975) The island dilemma: lessons of modern biogeographic studies for the design of natural reserves, Biological Conservation, Vol.7, No.2 (February 1975), pp. 129-146, ISSN 00063207

Durand, L. \& Vázquez, L. B. (2011). Biodiversity conservation discourses. A case study on scientists and government authorities in Sierra de Huautla Biosphere Reserve, Mexico. Land Use Policy, Vol.28, No.1 (January 2011), pp. 76-82, ISSN 0264-8377

Eagles, P. (2002) Trends in park tourism: Economics, finance and management. Journal of Sustainable Tourism, Vol.10, No.2, pp. 132-153, ISSN 09669582

Ellis, E. A. \& Porter-Bolland, L. (2008). Is community-based forest management more effective than protected areas? A comparison of land use/land cover change in two neighboring study areas of the Central Yucatan Peninsula, Mexico. Forest Ecology and Management, Vol.256, No.11 (November 2008), pp. 1971-1983, ISSN 0378-1127

Evanoff, R. J. (2005). Reconciling realism and constructivism in environmental ethics. Environmental Values, Vol.14, No.1 (February 2005), pp. 61-81, ISSN 09632719

Fall, J. (2002). Divide and rule: constructing human boundaries in 'boundless nature'. GeoJournal, Vol.58, No.4 (April 2002), pp. 243-251, ISSN 03432521

Fennell, D. A. \& Ebert, K. (2004). Tourism and the precautionary principle. Journal of Sustainable Tourism, Vol.12, No.6, pp. 461 - 479, ISSN 09669582

Fleishman, L. \& Feitelson, E. (2009). An application of the recreation level of service approach to forests in Israel. Landscape and Urban Planning, Vol.89, No.3-4 (February 2009), pp. 86-97, ISSN 0169-2046

Foster, B. C., Wang, D., Keeton, W. S., \& Ashton, M. S. (2010). Implementing sustainable forest management using six concepts in an adaptive management framework. Journal of Sustainable Forestry, Vol.29, No.1 (February 2010), pp. 79-108, ISSN 10549811 
Gatzogiannis, S., \& Poirazidis, K. (2010). The Dadia Forest Complex: stand development and forest management. In: The Dadia-Lefkimi-Soufli Forest National Park, Greece: Biodiversity, Management and Conservation, Catsadorakis, G., \& Källander, H. (Eds.), pp. 95-101. WWF-Greece, ISBN 978-960-7506-10-8, Athens

Gavashelishvili, A. \& McGrady, M. J. (2006). Geographic information system-based modelling of vulture species to carcass appearance in the Caucasus. Journal of Zoology, Vol.269, No.3 (July 2006), pp. 365-372, ISSN 09528369

Giessen, L.; Kleinschmit, D. \& Böcher, M. (2009). Between power and legitimacy Discourse and expertise in forest and environmental governance. Forest Policy and Economics, Vol.11, No.5-6 (October 2009), pp. 452-453, ISSN 1389-9341

Grill, A. \& Cleary, D. F. R. (2003). Diversity patterns in butterfly communities of the Greek nature reserve Dadia. Biological Conservation, Vol.114, No.3 (December 2003), pp. 427-436, ISSN 0006-3207

Hoffman, A. J., Gillespie, J. J., Moore, D. A., Wade-Benzoni, K. A., Thompson, L. L. and Bazerman, M. H. 1999. A mixed-motive perspective on the economics versus environment debate. American Behavioral Scientist, Vol.42, No.8 (May 1999), pp. 1254-1276, ISSN 00027642

Hovardas, T. (2005). Social representations on ecotourism - Scheduling interventions in Protected areas. Aristotle University, School of Biology, PhD-Thesis, Thessaloniki, Greece (in Greek with an English summary)

Hovardas, T. (2010). The contribution of social science research to the management of the Dadia Forest Reserve: nature's face in society's mirror. In: The Dadia-Lefkimi-Soufli Forest National Park, Greece: Biodiversity, Management and Conservation, Catsadorakis, G., \& Källander, H. (Eds.), pp. 253-263. WWF-Greece, ISBN 978-960-7506-10-8, Athens

Hovardas, T. \& Korfiatis, K. J. (2008). Framing environmental policy by the local press: case study from the Dadia Forest Reserve, Greece. Forest Policy and Economic, Vol.10, No.5 (April 2008), pp. 316-325, ISSN 13899341

Hovardas, T. \& Korfiatis, K. J. (2011). Towards a critical re-appraisal of ecology education: Scheduling an educational intervention to revisit the 'balance of nature' metaphor. Science \& Education, Vol.20, No.10 (October 2011), pp. 1039-1053

Hovardas, T. \& Poirazidis, K. (2006) Evaluation of the Environmentalist Dimension of Ecotourism at the Dadia Forest Reserve (Greece). Environmental Management, Vol.38, No.5 (November 2006), pp. 810-822, ISSN 0364152X

Hovardas, T. \& Stamou, G. P. (2006a) Structural and narrative reconstruction of representations on 'nature,' 'environment,' and 'ecotourism.' Society and Natural Resources, Vol.19, No.3 (March 2006), pp. 225-237, ISSN 08941920

Hovardas, T. \& Stamou, G. P. (2006b) Structural and narrative reconstruction of rural residents' representations of 'nature', 'wildlife', and 'landscape'. Biodiversity and Conservation, Vol.15, No.5 (May 2006), pp. 1745-1770, ISSN 09603115

Hovardas, T., Korfiatis K.J., \& Pantis, D.J. (2009). Environmental representations of local communities' spokespersons in protected areas. Journal of Community and Applied Social Psychology, Vol.19, No.6 (November 2009), pp. 459-472, ISSN 10529284

Hovik, S.; Sandström, C. \& Zachrisson, A. (2010). Management of protected areas in Norway and Sweden: Challenges in combining central governance and local participation. 
Journal of Environmental Policy and Planning, Vol.12, No.2 (June 2010), pp. 159-177, ISSN 1522-7200

Huttunen, S. (2009). Ecological modernisation and discourses on rural non-wood bioenergy production in Finland from 1980 to 2005. Journal of Rural Studies, Vol.25, No.2 (April 2009), pp. 239-247, ISSN 0743-0167

Kati, V. \& Sekercioglu, C. H. (2006). Diversity, ecological structure, and conservation of the landbird community of Dadia reserve, Greece. Diversity and Distributions, Vol.12, No.5 (September 2006), pp. 620-629, ISSN 13669516

Kati, V.; Dufrêne, M.; Legakis, A.; Grill, A. \& Lebrun, P. (2004). Conservation management for Orthoptera in the Dadia reserve, Greece. Biological Conservation, Vol.115, No.1 (January 2004), pp. 33-44, ISSN 0006-3207

Keskitalo, E. C. H. \& Lundmark, L. (2010). The controversy over protected areas and forestsector employment in Norrbotten, Sweden: Forest stakeholder perceptions and statistics. Society and Natural Resources, Vol.23, No.2 (February 2010), pp. 146-164, ISSN: 0894-1920

Kingsland, S. (2002). Designing nature reserves: adapting ecology to real-world problems. Endeavor, Vol.26, No.1, pp. 9-14, ISSN 0160-9327

Kleinschmit, D.; Böcher, M. \& Giessen, L. (2009). Discourse and expertise in forest and environmental governance - An overview. Forest Policy and Economics, Vol.11, No.5-6 (October 2009), pp. 309-312, ISSN 1389-9341

Klenner, W.; Kurz, W. \& Beukema, S. (2000). Habitat patterns in forested landscapes: management practices and the uncertainty associated with natural disturbances. Computers and Electronics in Agriculture, Vol.27, No.1-3 (June 2000), pp. 243-262, ISSN 0168-1699

Knight, R. L. \& Landres, P. B. (1998). Stewardship across boundaries. Island Press, ISBN 1559635169, Washington, D.C.

Laudati, A. A. (2010). The Encroaching Forest: Struggles Over Land and Resources on the Boundary of Bwindi Impenetrable National Park, Uganda. Society and Natural Resources, Vol.23, No.8 (August 2010), pp. 776-789, ISSN 1521-0723

Lawson, S. R.; Manning, R. E.; Valliere, W. A. \& Wang, B. (2003) Proactive monitoring and adaptive management of social carrying capacity in Arches National Park: an application of computer simulation modeling. Journal of Environmental Management, Vol.68, No.3 (July 2003), pp. 305-313, ISSN 0301-4797

Lebel, L., Contreras, A., Pasong, S., \& Garden, P. (2004). Nobody Knows Best: Alternative perspectives on forest management and governance in Southeast Asia. International Environmental Agreements: Politics, Law and Economics, Vol.4, No.2, pp. 111-127, ISSN 15679764

Leujak, W. \& Ormond, R. F. G. (2007). Visitor perceptions and the shifting social carrying capacity of South Sinai's coral reefs. Environmental Management, Vol.39, No.4 (April 2007), pp. 472-489, ISSN 0364152X

Liarikos, C. (2005). The Dadia Forest Reserve: Conservation Plan for the after-LIFE period. WWF Greece, Athens

Liarikos, C. (2010). Development trajectories and prospects in the Dadia-Lefkimi-Soufli Forest National Park. In: The Dadia-Lefkimi-Soufli Forest National Park, Greece: Biodiversity, Management and Conservation, Catsadorakis, G., \& Källander, H. (Eds.), pp. 47-62. WWF-Greece, ISBN 978-960-7506-10-8, Athens 
Lövbrand, E. (2009). Revisiting the politics of expertise in light of the Kyoto negotiations on land use change and forestry. Forest Policy and Economics, Vol.11, No.5-6 (October 2009), pp. 404-412, ISSN 1389-9341

Lund, D. H.; Boon, T. E. \& Nathan, I. (2009). Accountability of experts in the Danish national park process. Forest Policy and Economics, Vol.11, No.5-6 (October 2009), pp. 437445, ISSN 1389-9341

Machairas, I. \& Hovardas, T. (2005). Determining visitors' dispositions towards the designation of a Greek National Park. Environmental Management, Vol.36, No.1 (July 2005), pp. 73-88, ISSN 0364152X

Maes, W. H., Fontaine, M., Rongé, K., Hermy, M., \& Muys, B. (2011). A quantitative indicator framework for stand level evaluation and monitoring of environmentally sustainable forest management. Ecological Indicators, Vol.11, No.2 (March 2011), pp. 468-479, ISSN 1470160X

Manning, R. E.; Lawson, S.; Newman, P.; Laven, D. \& Valliere, W. (2002). Methodological issues in measuring crowding-related norms. Leisure Sciences, Vol.24, No.3-4 (July 2002), pp. 339-348, ISSN 01490400

Mulvihill, P. R. \& Milan, M. J. (2007). Subtle world: Beyond sustainability, beyond information. Futures, Vol.39, No.6 (August 2007), pp. 657-668, ISSN 0016-3287

Nygren, A. (2000). Environmental narratives on protection and production: nature-based conflicts in Rio San Juan, Nicaragua. Development and Change, Vol.31, No.4, pp. 807830, ISSN 0012155X

Nygren, A. (2004). Contested lands and incompatible images: the political ecology of struggles over resources in Nicaragua's Indio-Maiz Reserve. Society and Natural Resources, Vol.17, No.3 (March 2004), pp. 189-205, ISSN 08941920

Ojha, H. M.; Cameron, J. \& Kumar, C. (2009). Deliberation or symbolic violence? The governance of community forestry in Nepal. Forest Policy and Economics, Vol.11, No.5-6 (October 2009), pp. 365-374, ISSN 1389-9341

Ólafsdóttir, R. \& Runnströ, M. (2009). A GIS approach to evaluating ecological sensitivity for tourism development in fragile environments. A case study from SE Iceland. Scandinavian Journal of Hospitality and Tourism, Vol.9, pp. 22-38, ISSN 1502-2269

Parkins, J. R. (2006). De-centering environmental governance: A short history and analysis of democratic processes in the forest sector of Alberta, Canada. Policy Science, Vol.39, No.2 (June 2006), pp. 183-203, ISSN 00322687

Parkins, J. R. \& Davidson, D. J. (2008). Constructing the public sphere in compromised settings: Environmental governance in the Alberta forest sector. Canadian Review of Sociology, Vol.45, No.2 (May 2008), pp. 177-196, ISSN 17556171

Pelletier, N. (2010). Environmental sustainability as the first principle of distributive justice: Towards an ecological communitarian normative foundation for ecological economics. Ecological Economics, Vol.69, No.10 (August 2010), pp. 1887-1894, ISSN 0921-8009

Piñol, J.; Castellnou, M. \& Beven, K. (2007). Conditioning uncertainty in ecological models: Assessing the impact of fire management strategies. Ecological Modelling, Vol.207, No.1 (September 2007), pp. 34-44, ISSN 0304-3800

Plummer, R. \& Fennell, D. A. (2009). Managing protected areas for sustainable tourism: prospects for adaptive co-management. Journal of Sustainable Tourism, Vol.17, No.2 (March 2009), pp. 149-168, ISSN 1747-7646 
Poirazidis, K., Skartsi, T., Catsadorakis, G. (2002). Monotoring plan for the protected raea of Dadia-Lefkimi-Soufli Forest. WWF-Greece, Athens

Poirazidis, K.; Goutner, V.; Skartsi, T. \& Stamou, G. P. (2004). Nesting habitat modelling as a conservation tool for the Eurasian black vulture (Aegypius monachus) in Dadia Nature Reserve, northeastern Greece. Biological Conservation, Vol.118, No.2 (July 2004), pp. 235-248, ISSN 0006-3207

Prato, T. (2001). Modeling carrying capacity for national parks. Ecological Economics, Vol.39, No.3 (December 2001), pp. 321-331, ISSN 0921-8009

Prato, T. (2009). Fuzzy adaptive management of social and ecological carrying capacities for protected areas. Journal of Environmental Management, Vol.90, No.8 (June 2009), pp. 2551-2557, ISSN 0301-4797

Puhakka, R.; Sarkki, S.; Cottrell, S. P. \& Siikamäki, P. (2009) Local discourses and international initiatives: sociocultural sustainability of tourism in Oulanka National Park, Finland. Journal of Sustainable Tourism, Vol.17, No.5 (September 2009), pp. 529-549, ISSN 09669582

Reser, J. P. \& Bentrupperbäumer, J. M. (2005). What and where are environmental values? Assessing the impacts of current diversity of use of 'environmental' and 'World Heritage' values. Journal of Environmental Psychology, Vol.25, No.2 (June 2005), pp. 125-146, ISSN 02724944

Risse, T., 2000. Let's argue! Communicative action in world politics. International Organization, Vol.54, No.1, pp. 1-39, ISSN 00208183

Robbins, P. (2004). Political Ecology. Blackwell Puvblishing Ltd, ISSN 139781405102667, Oxford, UK

Roth, R. J. (2008). "Fixing" the Forest: The Spatiality of Conservation Conflict in Thailand. Annals of the Association of American Geographers, Vol.98, No.2 (April 2008), pp. 373391, ISSN 00045608

Ruppert-Winkel, C. \& Winkel, G. (2011). Hidden in the woods? Meaning, determining, and practicing of 'common welfare' in the case of the German public forests. European Journal of Forest Research, Vol. 130, No.3 (May 2011), pp. 421-434, ISSN 16124669

Sæpórsdóttir, A. D. (2010). Planning nature tourism in Iceland based on tourist attitudes. Tourism Geographies, Vol.12, No.1 (February 2010), pp. 25-52, ISSN 1470-1340

Schindler, S. (2010). Dadia National Park, Greece - an integrated study on landscape, biodiversity, raptor populations and conservation management. Doctoral Thesis, University of Vienna

Schindler, S.; Poirazidis, K. \& Wrbka, T. (2008). Towards a core set of landscape metrics for biodiversity assessments: A case study from Dadia National Park, Greece. Ecological Indicators, Vol.8, No.5 (September 2008), pp. 502-514, ISSN 1470160X

Seidl, J. \& Tisdell, C.A. (1999). Carrying capacity reconsidered: from Malthus' population theory to cultural carrying capacity. Ecological Economics, Vol.31, No.3 (December 1999), pp. 395-408, ISSN 0921-8009

Sharpley, R. \& Pearce, T. (2007) Tourism, marketing and sustainable development in the English National Parks: The role of national park authorities. Journal of Sustainable Tourism, Vol.15, No.5, pp. 557-573, ISSN 09669582

Skartsi, Th.; Elorriaga, J. N.; Vasilakis, D. P. \& Poirazidis, K. (2008). Population size, breeding rates and conservation status of Eurasian black vulture in the Dadia 
National Park, Thrace, NE Greece. Journal of Natural History, Vol.42, No.5 (February 2008), pp. 345-353, ISSN 0022-2933

Skartsi, Th., Elorriaga, J., \& Vasilakis, D. (2010). Eurasian Black Vulture: the focal species of the Dadia-Lefkimi-Soufli Forest National Park. In: The Dadia-Lefkimi-Soufli Forest National Park, Greece: Biodiversity, Management and Conservation, Catsadorakis, G., \& Källander, H. (Eds.), pp. 195-206. WWF-Greece, ISBN 978-960-7506-10-8, Athens

Sletto, B. (2010). The mythical forest, the becoming-desert: environmental knowledge production and the iconography of destruction in the Gran Sabana, Venezuela. Environment and Planning D: Society and Space, Vol.28, No.4, pp. 672-690, ISSN 02637758

Sletto, B. (2011). Conservation planning, boundary-making and border terrains: The desire for forest and order in the Gran Sabana, Venezuela. Geoforum, Vol.42, No.2 (March 2011), pp. 197-210, ISSN 0016-7185

Stamou, A. G.; Lefkaditou, A.; Schizas, D. \& Stamou, G. P. (2009). The discourse of environmental information: Representations of nature and forms of rhetoric in the information center of a Greek reserve. Science Communication, Vol.31, No.2 (December 2009), pp. 187-214, ISSN 10755470

Stavrakakis, Y. (1999). Lacan and the political. Routledge, ISSN 0415171873, London and New York

Steffek, J. (2009). Discursive legitimation in environmental governance. Forest Policy and Economics, Vol.11, No.5-6 (October 2009), pp. 313-318, ISSN 1389-9341

Stoffle, R. \& Minnis, J. (2008). Resilience at risk: epistemological and social construction barriers to risk communication. Journal of Risk Research, Vol.11, No.1-2 (JanuaryMarch 2008), pp. 55-68, ISSN 1366-9877

Sugimura, K. \& Howard, T. E. (2008). Incorporating social factors to improve the Japanese forest zoning process. Forest Policy and Economics, Vol.10, No.3 (January 2008), pp. 161-173, ISSN 1389-9341

Svoronou, E. (2000). Planning pilot actions for the development of ecotourism. Greek National Tourism Organization and WWF-Greece, Athens (in Greek)

Svoronou, E. \& Holden, A. (2005). Ecotourism as a tool for nature conservation: The role of WWF Greece in the Dadia-Lefkimi-Soufli Forest Reserve in Greece. Journal of Sustainable Tourism, Vol.13, No.5 (November 2005), 2005, pp. 456-467, ISSN 09669582

Swart, R. J.; Raskin, P. \& Robinson, J. (2004). The problem of the future: Sustainability science and scenario analysis. Global Environmental Change, Vol.14, No.2 (July 2004), pp. 137-146, ISSN 09593780

Tàbara, D.; Saurí, D. \& Cerdan, R. (2003). Forest fire risk management and public participation in changing socioenvironmental conditions: A case study in a Mediterranean region. Risk Analysis, Vol. 23, No.2 (2003), pp. 249-260, ISSN 02724332

Triantakonstantis, D. P.; Kollias, V. J. \& Kalivas, D. P. (2006). Forest re-growth since 1945 in the Dadia Forest nature reserve in northern Greece. New Forests, Vol.32, No.1 (July 2006), pp. 51-69, ISSN 0169-4286

Uddhammar, E. (2006). Development, conservation and tourism: conflict or symbiosis? Review of International Political Economy, Vol.13, No.4 (October 2006), pp. 656-678, ISSN 1466-4526 
Van Gossum, P., Arts, B., De Wulf, R., \& Verheyen, K. (2011). An institutional evaluation of sustainable forest management in Flanders. Land Use Policy, Vol.28, No.1 (January 2011), pp. 110-123, ISSN 02648377

Vasilakis, P. D.; Poirazidis, S. K. \& Elorriaga, N. J. (2008). Range use of a Eurasian black vulture (Aegypius monachus) population in the Dadia National Park and the adjacent areas, Thrace, NE Greece. Journal of Natural History, Vol.42, No.5 (February 2008), pp. 355-373, ISSN 0022-2933

Veenman, S.; Liefferink, D. \& Arts, B. (2009). A short history of Dutch forest policy: The 'deinstitutionalisation' of a policy arrangement. Forest Policy and Economics, Vol.11, No.3 (May 2009), pp. 202-208, ISSN 1389-9341

Velázquez, A.; Cué-Bär, E. M.; Larrazábal, A.; Sosa, N.; Villaseňor, J. L.; McCall, M. \& IbarraManríquez, G. (2009). Building participatory landscape-based conservation alternatives: A case study of Michoacán, Mexico. Applied Geography, Vol.29, No.4 (December 2009), pp. 513-526, ISSN 0143-6228

Vierikko, K.; Vehkamäki, S.; Niemelä, J.; Pellikka, J. \& Lindén, H. (2008). Meeting the ecological, social and economic needs of sustainable forest management at a regional scale. Scandinavian Journal of Forest Research, Vol.23, No.5 (October 2008), pp. 431-444, ISSN 1651-1891

Von Detten, R. (2011). Sustainability as a guideline for strategic planning? The problem of long-term forest management in the face of uncertainty. European Journal of Forest Research, Vol. 130, No.3 (May 2011), pp. 451-465, ISSN 16124669

Warren, W. A. (2007). What Is a Healthy Forest? Definitions, Rationales, and the Lifeworld. Society and Natural Resources, Vol.20, No.2 (February 2007), pp. 99-117, ISSN 15210723

Winkel, G. (in press). Foucault in the forests - A review of the use of 'Foucauldian' concepts in forest policy analysis. Forest Policy and Economics, doi:10.1016/j.forpol. 2010.11.009, ISSN 1389-9341

Wolfslehner, B., \& Seidl, R. (2010). Harnessing ecosystem models and multi-criteria decision analysis for the support of forest management. Environmental Management, Vol.46, No.6 (December 20010), pp. 850-861, ISSN 0364152X

Wood, B. (2000). Room for nature? Conservation management of the Isle of Rum, UK and prospects for large protected areas in Europe. Biological Conservation, Vol.94, No.1 (June 2000), pp. 93-105, ISSN 00063207

Wynne, B., 2006. Public engagement as a means of restoring public trust in science-hitting the notes, but missing the music? Community Genetics, Vol.9, No.3 (May 2006), pp. 211-220, ISSN 14222795

Zacarias, D. A.; Williams, A. T. \& Newton, A. (2011). Recreation carrying capacity estimations to support beach management at Praia de Faro, Portugal. Applied Geography, Vol.31, No.3 (July 2011), pp. 1075-1081, ISSN 0143-6228 


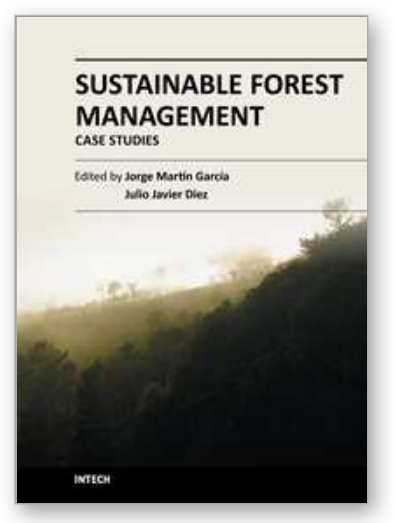

\author{
Sustainable Forest Management - Case Studies \\ Edited by Dr. Julio J. Diez
}

ISBN 978-953-51-0511-4

Hard cover, 258 pages

Publisher InTech

Published online 11, April, 2012

Published in print edition April, 2012

The concept of forest sustainability dates from centuries ago, although the understanding of sustainable forest management (SFM) as an instrument that harmonizes ecological and socio-economic concerns is relatively new. The change in perspective occurred at the beginning of the 1990s in response to an increased awareness of the deterioration of the environment, in particular of the alarming loss of forest resources. The book collects original case studies from 12 different countries in four continents (Africa, America, Asia and Europe). These studies represent a wide variation of experiences from developing and developed countries, and should clarify the current status of SFM worldwide and the problems associated with its implementation.

\title{
How to reference
}

In order to correctly reference this scholarly work, feel free to copy and paste the following:

Tasos Hovardas (2012). Can Forest Management in Protected Areas Produce New Risk Situations? A MixedMotive Perspective from the Dadia-Soufli-Lefkimi Forest National Park, Greece, Sustainable Forest Management - Case Studies, Dr. Julio J. Diez (Ed.), ISBN: 978-953-51-0511-4, InTech, Available from: http://www.intechopen.com/books/sustainable-forest-management-case-studies/can-forest-management-inprotected-areas-produce-new-risk-situations-a-mixed-motive-perspective-to-p

\section{INTECH}

open science | open minds

\section{InTech Europe}

University Campus STeP Ri

Slavka Krautzeka 83/A

51000 Rijeka, Croatia

Phone: +385 (51) 770447

Fax: +385 (51) 686166

www.intechopen.com

\section{InTech China}

Unit 405, Office Block, Hotel Equatorial Shanghai

No.65, Yan An Road (West), Shanghai, 200040, China 中国上海市延安西路65号上海国际贵都大饭店办公楼 405 单元

Phone: +86-21-62489820

Fax: +86-21-62489821 
(C) 2012 The Author(s). Licensee IntechOpen. This is an open access article distributed under the terms of the Creative Commons Attribution 3.0 License, which permits unrestricted use, distribution, and reproduction in any medium, provided the original work is properly cited. 